Acta Universitatis Nicolai Copernici • Pedagogika XL/2/2020

Nauki Humanistyczno-Społeczne • Zeszyt 452

DOI: http://dx.doi.org/10.12775/AUNC_PED.2020.017

\title{
Gvantsa Przybyłowska
}

Instytut Języka Polskiego im. Ireny Bajerowej

Uniwersytet Śląski

https://orcid.org/0000-0001-9677-864X

\section{ToŻSAMOść JĘZYKOWA GRUZINóW \\ A JĘZYK ROSYJSKI}

\section{Linguistic Identity of Georgias and the Russian Language}

\begin{abstract}
Abstrakt
Droga do zachowania języka gruzińskiego jako języka państwowego w sytuacjach zagrożenia była trudna. Te procesy nie trwały po 20-50 lat, ale o wiele dłużej. W różnych okresach historycznych Gruzja była okupowana, dzielona przez „inne”, „obce” narody, które kulturowo nie miały wiele wspólnego z Gruzją. Kultura gruzińska mocno ucierpiała, w tym język gruziński.

W Gruzji znajomość języka rosyjskiego, jak pokazują wyniki, nadal jest na wysokim poziomie. Ci, którzy urodzili się w ZSRR lub krótko po rozpadzie Związku Radzieckiego, musieli się uczyć języka rosyjskiego. Znajomość czy nieznajomość języka może być tylko kwestią znajomości obcych języków w danym państwie, a nie musi koniecznie być związana z prorosyjską polityką państwa. W propagandzie nauczania języka rosyjskiego dużą rolę mogą odgrywać dobre stosunki z Rosją (np. niektóre kraje postradzieckie), ale nie zawsze tak musi być (np. w przypadku Gruzji). Wysoki odsetek osób znających język rosyjski może być spowodowany położeniem geograficznym (kraj sąsiadujący z Rosją), historią (Imperium Rosyjskie, ZSRR), interesami (wysoki procent
\end{abstract}


rosyjskich inwestycji, np. w Armenii), edukacją („najlepsze” uniwersytety są w Rosji, więc warto się uczyć rosyjskiego), kulturą (Słowianie) itd.

Słow a kluczowe: język rosyjski w Gruzji, świadomość językowa Gruzinów, tożsamość językowa Gruzinów

\begin{abstract}
The preservation of the Georgian language was not an easy task at times when its official language status was endangered. These efforts did not last 20 or 50 years, but much longer. At various times in history, Georgia has been occupied, divided by "other", "foreign" nations that culturally had little in common with Georgia. Georgian culture has suffered greatly, including the Georgian language.

In Georgia, Russian language proficiency is still at a high level, as the results show. Those who were born in the USSR or shortly after its collapse had to learn Russian. Knowing a language can be merely a matter of foreign languages knowledge in a given country, which is not necessarily linked to proRussian state policy. Good relations with Russia can play a significant role in the propaganda of Russian language teaching (e.g. in some former Soviet states), but this is not always necessarily the case (e.g. in the case of Georgia). The high percentage of people knowing Russian may be due to geographical location (being neighbors with Russia), history (Russian Empire, USSR), interests (high percentage of Russian investments, e.g. in Armenia), education ("best" universities are in Russia, so it is worth learning Russian), culture (Slavs), etc.
\end{abstract}

Keywords: Russian language in Georgia, Georgian language consciousness, Georgian linguistic identity

\title{
Wstęp
}

T Tielu językoznawców, socjologów, antropologów czy kulturologów uważa, że język jest jednym z najważniejszych czynników kształtujących ludzką tożsamość. Według Georges’a Charbonniera ,język jest zasadniczym instrumentem, uprzywilejowanym środkiem, dzięki któremu przyswajamy kulturę naszej grupy. [...] W końcu i przede wszyst- 
kim język jest najdoskonalszym ze wszystkich przejawów porządku kulturowego, tworzących systemy na tej czy innej zasadzie"1. Benjamin Lee Whorf twierdzi, że ,język organizuje nasze doświadczenie. Zwykle sądzimy, że język stanowi po prostu technikę wyrażenia myśli i nie zdajemy sobie sprawy z tego, że jednocześnie klasyfikuje on i podporządkowuje strumień doznań zmysłowych, wytwarzając tym samym pewien obraz świata, pewien wycinek rzeczywistości"2. Marian Bugajski pisze: „nie ulega wątpliwości, że tożsamość językowa jest jednym z najważniejszych, a może nawet najważniejszym czynnikiem kształtującym tożsamość człowieka"3. Z kolei Jolanta Tambor uważa, że roli języka w tożsamości nie możemy rozumieć jednoznacznie. Zdaniem autorki język nie jest jedynym i ostatecznym składnikiem tożsamości, ale jest jednym z najważniejszych:

Zależność języka i tożsamości/identyfikacji jest dwustronna. Wszyscy badacze zajmujący się tożsamością (socjologowie, antropolodzy, kulturolodzy, językoznawcy) twierdzą, że język należy do podstawowych czynników/składników określających ludzką tożsamość, choć oczywiście nie jest to zależność prosta i jednoznaczna. Są wszak państwa, w których mówi się kilkoma językami (Szwajcaria, Kanada), są języki, które są oficjalnymi językami w kilku różnych państwach (np. angielski w Wielkiej Brytanii, USA, Kanadzie, Australii). W tym wypadku mowa jest jednak o narodach państwowych - dla nich język nie stanowi czynnika konstytutywnego tożsamości ${ }^{4}$.

Są narody wielojęzyczne, np. Hindusi, są narody kilkujęzyczne, np. Szwajcarzy, którzy nie mają jednego języka powszechnego w literaturze czy w nauce. Inny naród europejski, Irlandia, przyjął język angielski jako mowę potoczną i jako język literacki, ale „rzecz jasna, przypadki te nie zmieniają faktu, że dla wielu narodów nowoczesnych wykształ-

1 C. Lévi-Strauss, G. Charbonnier, Rozmowy z Claude Lévi-Straussem / Georges Charbonnier, Warszawa 1968, s. 142.

2 B.L. Whorf, Język, myśl i rzeczywistość, Warszawa 1982, s. 96.

3 M. Bugajski, Język w komunikowaniu, Warszawa 2006, s. 61.

4 J. Tambor, Brak normy dla gwary, w: Dialektologia. Materiaty pomocnicze, red. A. Skudrzyk, E. Rudnicka-Fira, Katowice 2010, s. 75. 
cenie wspólnego języka narodowego było jednym z najważniejszych czynników kulturowej odrębności"s. Do takich narodów można zaliczyć Gruzinów.

W Gruzji językiem narodowym i państwowym jest gruziński, który kształtował się razem z rozwojem kraju i został zapisany w Konstytucji. W Ustawie o języku gruzińskim czytamy ${ }^{6}$ :

Język gruziński jest historyczno-kulturowym dziedzictwem Gruzji i niezbędnym warunkiem jej państwowości. Jest to wspólna własność państwowa każdego obywatela Gruzji. Państwo Gruzji w tym języku wykonuje wszystkie swoje funkcje, chroni go i określa swoją politykę wobec niego jako języka państwowego, politykę funkcjonowania i rozwoju.

Stan Gruzji jednocześnie podtrzymuje i umacnia wielowiekową tradycję współistnienia języków i kultur w tym kraju. Uważamy za niedopuszczalne lekceważenie jakiegokolwiek naruszania praw innych języków przez obywateli Gruzji...7

W niniejszym artykule tożsamość językową omówię na przykładzie relacji pomiędzy językiem gruzińskim i rosyjskim, a także spróbuję ustalić, czy język odgrywa ważną rolę w kształtowaniu poczucia przynależności narodowej Gruzinów. W Polsce często można spotkać się z różnymi stereotypami na temat Gruzji, np. gruziński jest bardzo podobny do języka rosyjskiego, w Gruzji piszą za pomocą cyrylicy, w Gruzji wszyscy mówią po rosyjsku. Jednym z powodów takiego myślenia jest to, że Gruzja była częścią ZSRR (a wcześniej częścią Imperium Rosyjskiego) i choć minęło już 20 lat od czasu uzyskania niepodległości, kraj nadal jest kojarzony z rosyjską kulturą. Warto wspomnieć, że stereotypy są wzajemne: w Gruzji wiele osób też jest zaskoczonych, gdy przekonują się, że Polacy wcale nie mówią po rosyjsku. Należy podkre-

5 P. Rybicki, Naród i państwo. Z rozważań nad relacją między dwiema postaciami wielkiej społeczności, w: Naród, kultura, osobowość: księga poświęcona Profesorowi Józefowi Chałasińskiemu, red. A. Kłoskowska, Wrocław 1983, s. 90.

6 We wszystkich cytatach ze źródeł gruzińskich, jeśli nie podano inaczej, tłumaczenie własne autorki. Omawiając terminy gruzińskie, często podaję od razu polski odpowiednik, jeśli wcześniej tę odpowiedniość wskazałam.

7 Ustawa o języku państwowym. Internet: https://matsne.gov.ge/ka/document/view/2931198?publication=3 (dostęp: 22.03.2021). 
ślić, że dzięki rozwojowi bazy turystycznej w Gruzji w ostatnich 10 latach coraz więcej osób odwiedziło ten kraj, w tym Polacy, co częściowo zmieniło wiedzę i nastawienie podróżników do Gruzji, ale i tak, po powrocie, od wielu z nich można usłyszeć, że w Gruzji ze wszystkimi można porozumieć się w języku rosyjskim ${ }^{8}$. Czy to prawda?

Odnosząc się do pytania, warto zwrócić uwagę na jedną kwestię: zazwyczaj rynek turystyczny dopasowany jest do potrzeb. Według najnowszych statystyk do Gruzji najwięcej turystów przyjeżdża właśnie z krajów rosyjskojęzycznych lub postradzieckich, gdzie rosyjski nadal jest popularnym językiem. Na stronie Gruzińskiej Narodowej Administracji Turystyki można zapoznać się z danymi obrazującymi liczbę osób podróżujących do Gruzji od 2011 do 2020 roku. Dane te kształtują się następująco:

\section{Tabela 1}

Liczba osób przyjeżdżających do Gruzji w roku 2001 i 2019

\begin{tabular}{lcc}
\hline \multicolumn{1}{c}{ Kraje } & $\begin{array}{c}\text { Liczba przyjeżdżających } \\
\text { w 2011 roku }\end{array}$ & $\begin{array}{c}\text { Liczba przyjeżdżających } \\
\text { w 2019 roku }\end{array}$ \\
\hline Azerbejdżan & 614285 & 1526619 \\
\hline Turcja & 567317 & 1156513 \\
\hline Armenia & 562164 & 1365048 \\
\hline Rosja & 220294 & 1471558 \\
\hline Ukraina & 53734 & 207667 \\
\hline Niemcy & 17812 & 15717 \\
\hline Polska & 11236 & 27952 \\
\hline Francja & 8436 & $\mathbf{9 3 5 7 9 6 4}$ \\
\hline $\begin{array}{l}\text { Łącznie liczba osób } \\
\text { przyjeżdżających do Gruzji }\end{array}$ & $\mathbf{3 1 1 5} \mathbf{5 2 7}$ & \\
\hline
\end{tabular}

Źródło: opracowanie własne na podstawie: https://gnta.ge/ge/\%e1\%83\%a1\%e1\%83\%a$2 \%$ e $1 \% 83 \% 90 \%$ e $1 \% 83 \%$ a $2 \%$ e $1 \% 83 \% 98 \%$ e $1 \% 83 \%$ a $1 \%$ e $1 \% 83 \%$ a $2 \%$ e $1 \% 83 \% 98 \%$ e1\%83\%99\%e1\%83\%90/ (dostęp: 28.03.2021).

8 Prawie każdy Gruzin posługuje się ptynnie językiem rosyjskim. Internet: https://www.tamadatour.pl/blog/jezyk-zwyczaje-w-gruzji/ (dostęp: 22.03.2021). 
W tabeli umieściłam pięć krajów, z których najwięcej osób przyjeżdża do Gruzji (nie wszyscy przyjeżdżają turystycznie), a także dane podróżników z Polski, Niemiec i Francji, aby pokazać różnicę pomiędzy liczbą turystów wymienionych krajów i osób podróżujących z Unii Europejskiej. Wyniki pokazują, że liczba odwiedzających Gruzję od 2011 do 2019 roku wzrosła trzykrotnie, liczba turystów przybywających z Polski do Gruzji wzrosła siedmiokrotnie. Warto zaznaczyć, że duży ruch turystyczny między Turcją a Gruzją nie wynika wcale z chęci Turków do zwiedzania Gruzji, raczej spowodowany jest tym, że sporo Gruzinów pracuje w Turcji i od czasu do czasu odwiedza swoją ojczyznę.

Na oficjalnej stronie Gruzińskiej Policji można zobaczyć raport dotyczący liczby turystów odwiedzających Gruzję w latach 2006-20159. Według danych w 2011 roku 2822363 osoby odwiedziły Gruzję w celach turystycznych. W raporcie odnotowano również, że w 2011 roku z Unii Europejskiej włącznie przyjechało 136 975, z Rosji 278458 osób ${ }^{10}$. Należy zaznaczyć, że liczba turystów z Europy co roku rośnie, ale nadal nie przekracza liczby osób przyjeżdżających z Rosji i z innych krajów rosyjskojęzycznych. Pokazując wyniki, chciałam zasugerować, że popularność języka rosyjskiego może także wynikać z potrzeb turystycznych, dlatego Polacy podróżujący do Gruzji często mogą mieć do czynienia $\mathrm{z}$ rosyjskojęzyczną obsługą $\mathrm{w}$ miejscach turystycznych, co nie oznacza jednak, że wszyscy Gruzini mówią po rosyjsku. Dodatkowo znajomość czy nieznajomość języka może być tylko kwestią znajomości obcych języków w danym kraju, a nie musi koniecznie być związana z prorosyjską polityką państwa. W propagandzie nauczania języka rosyjskiego dużą rolę mogą odgrywać dobre stosunki z Rosją (np. niektóre kraje postradzieckie), ale nie zawsze tak musi być (np. w przypadku Gruzji). Wysoki odsetek osób znających język rosyjski może być spowodowany położeniem geograficznym (kraj sąsiadujący z Rosją), historią (Imperium Rosyjskie, ZSRR), interesami (wysoki procent rosyjskich inwestycji, np. w Armenii), edukacją („najlepsze” uniwersytety są w Rosji, więc warto się uczyć rosyjskiego), kulturą (Słowianie) itd.

9 Wyniki trochę się różnią od wyników podanych przez Gruzińską Narodową Administrację Turystyki, ale nie zmieniają przedstawionej ogólnej sytuacji.

${ }^{10}$ W 2014 r. z Unii Europejskiej przyjechały 230323 osoby, z Rosji 810233. 


\section{Stosunek Gruzinów do tożsamości językowej}

Badania jakościowe, które prowadziłam w latach 2017-2020, miały na celu zebranie informacji na temat stanu przynależności językowej Gruzinów oraz ich stosunku do tożsamości narodowej. W badaniach brały udział 234 osoby, w tym 138 kobiet i 96 mężczyzn. Wśród respondentów znalazły się osoby z Abchazji, które wyemigrowały do Gruzji w latach 90., oraz ormiańscy Gruzini. W badanej grupie najwięcej było ludzi młodych przed czterdziestym rokiem życia. Badania przeprowadzono techniką ankietową oraz otwartego wywiadu pogłębionego. Zebrany materiał badawczy obejmował odpowiedzi na 22 pytania, które dzieliły się na dwie części: część dla wszystkich mieszkańców Gruzji i część dla tych, którzy mówią językami kartwelskimi (swański, megrelski, lazyjski), do tego dochodziły pytania demograficzne dotyczące płci, wieku, miejsca i regionu zamieszkania respondentów.

Badania jakościowe umożliwiły także analizę spraw subiektywnych i niemierzalnych, ale równocześnie prowadziłam analizy ilościowe. Niektóre rozmowy zostały nagrane w formie audio, a w przypadku, gdy nagranie rozmowy było niemożliwe, sporządzano szczegółową notatkę, zdarzały się rozmowy prowadzone przez Skype'a czy na Facebooku. Kolejnym etapem badań była analiza zebranego materiału. Ponieważ w źródłach gruzińskich nie znalazłam żadnych badań o podobnej tematyce, w metodologii opierałam się na polskich pracach naukowych, a szczególnie na rozprawie Joanny Woźniakiewicz Języki kaszubski i friulijski. Zagrożenia i szanse. Porównanie stopnia zaawansowania procesów odchodzenia od języka (Kraków 2013).

Ze względu na cel artykułu nie będę przedstawiać całości zebranych materiałów, tylko część, która dotyczy omawianej tematyki. Jak już wspominano, językiem państwowym w Gruzji jest gruziński: ,język gruziński jest historyczno-kulturowym dziedzictwem Gruzji i niezbędnym warunkiem jej państwowości. [...] Jednocześnie Gruzja podtrzymuje i umacnia wielowiekową tradycję współistnienia języków i kultur oraz harmonijnego rozwoju w kraju" - czytamy w Ustawie o statusie ję- 
zyka państwowego w Gruzji z 2017 roku' ${ }^{11}$. Zapisy w ustawie nie są jednoznacznym wskaźnikiem, że Gruzini silnie identyfikują się z własnym językiem. Tak jak pisze Roman Szul, język może mieć funkcję komunikacyjną, która służy porozumiewaniu się ludzi, i funkcję symboliczną, która powoduje utożsamianie się ludzi z danym językiem, a tym samym integrację ludzi w społeczeństwie ${ }^{12}$. Autor twierdzi, że nie zawsze każdy język pełni obie funkcje jednocześnie. Bywają społeczności, które w codziennej komunikacji posługują się jednym językiem, a za swój symbol uważają inny (np. Białoruś). Częste są również przypadki częściowej rozbieżności między językiem komunikacyjnym a symbolicznym, kiedy część danej wspólnoty narodowej nie używa na co dzień (a nawet nie zna) języka uważanego za symbol tożsamości narodowej i odwrotnie, kiedy część użytkowników danego języka nie uważa go za swój symbol narodowy ${ }^{13}$.

Aby ustalić, czy Gruzini uważają swój język za symbol narodowy, podczas wspomnianych badań zadałam respondentom następujące pytanie: Czy Pan/Pani uważa, ̇̇e język gruziński jest jednym z najważniejszych komponentów identyfikacji Gruzinów? $(\mathrm{n}=226)$. Zdecydowana większość respondentów (85\%) zaznaczyła, że gruziński jest bardzo ważnym składnikiem przynależności do swojego kraju, 14\% uważa, że jest ważnym komponentem, nikt nie zaznaczył, że jest częściowo ważny, tylko jedna osoba stwierdziła, że w ogóle nie jest istotny. Swoje wypowiedzi respondenci uzupełniali następującą argumentacją:

W byciu Gruzinem język odgrywa bardzo ważną rolę. W naszej historii nie było momentu, żebyśmy stracili nasz język. Jak myślisz, dlaczego nie mówimy po arabsku, turecku lub nawet rosyjsku? Dużo osób poświęciło za to swoje życie, cały czas walczyli o zachowanie języka. Skoro przez tyle wieków mówimy po gruzińsku, uważam, że gdybyśmy stracili język stracilibyśmy tożsamość gruzińską.

11 Prawo o języku państwowym. Internet: https://matsne.gov.ge/ka/document/view/2931198?publication=3 (dostęp: 4.05.2021).

12 R. Szul, Język. Naród. Państwo, Warszawa 2009, s. 47.

13 Tamże, s. 23. 
Jeśli będziemy wspominać Ilię Czawczawadzego, który nam mówił, co jest najważniejsze w życiu: język, ojczyzna i wiara, zauważymy, że te 3 komponenty idealnie oddają charakter narodu gruzińskiego. Jeśli porozmawiamy o innych narodach, np. o Polakach, oni mają inne priorytety w życiu: Bóg, Honor, Ojczyzna, gdzie w ogóle nie ma mowy o języku. Przypomniałam sobie, jak w 1978 roku rząd radziecki próbował odebrać status języka narodowego językowi gruzińskiemu, co w całej Gruzji spowodowało ogromne demonstracje i skończyło się zwycięstwem Gruzji. To wszystko oznacza, że w przypadku Gruzji, język naprawdę jest bardzo silnym identyfikatorem w byciu Gruzinem.

Uważam, że język gruziński oczywiście jest ważny, ale nie jest koniecznym komponentem bycia Gruzinem. Przypominam sobie gruzińsko-francuski film Peswebi (Korzenie) ${ }^{14}$, gdzie główny bohater zapomina języka gruzińskiego, ale do końca życia pozostaje Gruzinem.

Moim zdaniem, i wierzę w to, język gruziński jest bardzo ważnym czynnikiem gruzińskości, jak mówi Ilia Czawczawadze: trzy boskie skarby otrzymaliśmy od przodków: ojczyzna, język i wiara. Język ze swoją ważnością jest przyrównany do Boga i ojczyzny; język bez ojczyzny nie istnieje, a ojczyzna zawiera język. Kiedy mieszkałam w Niemczech, zobaczyłam, jak bardzo ludzie szanują swój język, jest wiele stypendiów czy programów dla obcokrajowców. W ten sposób próbują chronić ojczyznę i wzmacniają państwo. Pamiętam, jak byłam w klasie V-VI, zadawałam nauczycielowi pytania: kiedy człowiek emocjonalnie zmienia narodowość? Czy wtedy, kiedy wyjedzie z kraju i tam zamieszka? A nauczyciel mi odpowiadał: kiedy zacznie myśleć $\mathrm{w}$ innym języku. To zapamiętałam głęboko. Język - moim zdaniem - jest najsilniejszym identyfikatorem narodowości. Nawet w cerkwi, podczas mszy usłyszałam, że „język jest święty” - i zgadzam się z tym.

Martin Heidegger mówi, że ,język jest domostwem ludzkiego bycia” i zgadzam się z tym, język determinuje nasze istnienie i myślenie, nawet jeśli „twój język” jest „najprostszym” językiem świata.

Język jest pierwszym i najważniejszym składnikiem tożsamości. Mam w pamięci książkę Gurama Pandzikidze, gdzie autor pisze: ,język jest naszym sumieniem, którego nie można stracić". Gruzin, jeśli nie postawi na najważniejszym miejscu swojego języka, nie jest prawdziwym Gruzinem.

${ }^{14}$ Film z 1987 r. o gruzińskich imigrantach we Francji. 
Jest jednym z ważnych czynników, ale nie najważniejszym. Język tak samo odróżnia nas od innych, a równocześnie nas włącza i kształtuje nas jako naród.

Oczywiście, że tak. Na przykład Ferejdańscy Gruzini ${ }^{15}$ utrzymali swoją tożsamość za pomocą języka, właśnie dzięki językowi gruzińskiemu nie asymilowali się z Irańczykami. Stracili swoją wiarę chrześcijańską, ponieważ mieszkają na obcych ziemiach, daleko od ojczyzny, ale nie stracili swojego języka.

Urodziłam się za granicą. Do 17 roku życia nie mówiłam po gruzińsku, ale wychowałam się według gruzińskich tradycji i zwyczajów, więc uważałam, że to wystarczy do bycia Gruzinem. Jednak kiedy poznałam język, nauczyłam się mówić po gruzińsku, dopiero wtedy poczułam, że naprawdę jestem Gruzinką, więc tak, zgadzam się z twierdzeniem, że język jest bardzo ważnym czynnikiem tożsamości.

Na początku pomyślałam, że jest ważnym elementem, ale późnej przypomniałam sobie Irlandię, mało osób mówi po irlandzku, ale mają wyraźne poczucie tożsamości narodowej.

W identyfikacji narodowej kluczową rolę odgrywa miejsce urodzenia, w tym religia, kultura i język. Nasz język idealnie oddaje nasz charakter i nazywa każdą rzecz w odpowiedni sposób. Inny język nie jest w stanie oddać tego wszystkiego. Nie mogę wyobrazić sobie Gruzji bez języka i alfabetu. Język jest „matką” narodu. Nasi przodkowie poświęcili swoje życie, żeby to wszystko utrzymać.

Podczas badań aż 14 razy wspomniano o dewizie, której autorem jest znany gruziński pisarz Ilia Czawczawadze. W XIX wieku przedstawił on kryteria autoidentyfikacji narodowej Gruzinów, na którą składają się trzy komponenty: ojczyzna (Gruzja), język (gruziński oraz pismo gruzińskie) i religia (prawosławna). Uważano, że jeśli osoba nie mówiła i nie pisała po gruzińsku, nie kochała swojego kraju oraz jeśli nie była wyznania prawosławnego - nie była Gruzinem. Dla lepszego

15 Etniczni Gruzini, których szach Persji Abbas I Wielki deportował z Gruzji do Iranu. W Iranie stworzyli swoją gwarę, która jest podobna do dialektu kachetyjskiego. 
zrozumienia roli języka w tożsamości Gruzinów bardziej skonkretyzowałam pytanie: Czy Pan/Pani zgadza się ze zdaniem: „Jeśli ktoś nie zna języka gruzińskiego, to nie jest Gruzinem"? (n = 170). Okazało się, że $67 \%$ respondentów zgadza się z tym stwierdzeniem, a tylko $29 \%$ osób zaznaczyło, że język może jest ważnym komponentem tożsamości, ale nie najważniejszym, nie aż tak ważnym, żeby jego znajomość czy nieznajomość zdecydowała o przynależności narodowej (4\% nie ma zdania). Część osób, które nie zgadzały się z tym stwierdzeniem, starała się wyjaśnić swoje podejście za pomocą przykładów z życia prywatnego czy historii, np.:

Uważam, że ogólnie język jest ważnym komponentem w identyfikacji człowieka, szczególnie wtedy, gdy oprócz jednego narodu nikt nie mówi w tym języku i identyfikacja jest zdecydowanie prostsza. Gruzina mieszkającego za granicą, który słabo mówi po gruzińsku, nie można uznać za nie-Gruzina, ponieważ język nie jest jedynym identyfikatorem w tożsamości narodowej.

Język gruziński jest nieodłącznym elementem kultury gruzińskiej, ale nie jest najważniejszym czynnikiem w byciu Gruzinem. Z powodu specyfiki Gruzji wiele osób mających gruzińskie obywatelstwo nie mówi po gruzińsku; czasami nawet mają inne narodowości, ale co ważne, czują się Gruzinami. Na przykład moja mama, która z pochodzeniem jest Gruzinką, używa języka rosyjskiego jako języka komunikacji. Mimo tego, nie pomyślałaby, że ktoś może uznać ją za nie-Gruzinkę.

W byciu Gruzinem nie wystarczy znać tylko język, ale może to pomóc odnaleźć siebie i poznać gruziński charakter.

Z odpowiedzi wynika, że Gruzini bardzo dużą wagę przywiązują do języka, ale na pytanie: Jakie cechy (cechę) powinna mieć osoba, żeby stwierdzić, że jest prawdziwym Gruzinem? $(\mathrm{n}=226)$ tylko 21 osób wspominało o ważności języka gruzińskiego ${ }^{16}$. Najwięcej osób odpowiedziało, że prawdziwy Gruzin przede wszystkim musi kochać ojczyznę (choć w miłości do ojczyzny tkwi również duma z języka). Drugim najważniej-

16 Pytanie było otwarte, żeby nie ograniczać respondentów, więc uczestnicy badań sami mogli wpisywać odpowiedzi. 
szym wskaźnikiem gruzińskości okazała się gościnność; 43 osoby uznały, że prawdziwy Gruzin powinien być religijny, nie zaznaczając konkretnej wiary (tylko 3 osoby użyły słowa „prawosławni”). Spośród respondentów 25 osób napisało, że bardzo trudno odpowiedzieć na to pytanie, z czego 8 osób całkowicie zrezygnowało z odpowiedzi, a 17 osób mimo trudności spróbowało opisać „prawdziwego Gruzina”. Oto kilka przykładów odpowiedzi:

Każde pokolenie jest inne. Pokolenie naszych rodziców ma radziecką mentalność, mówiąc po rosyjsku, są typowymi „Gruzinami”"17. Lubią długie supry, często niepotrzebnie zmuszają gości do picia wina w dużych ilościach, bez granic podają na stole jedzenie, myślą, że nepotyzm jest czymś dobrym, korupcja dla nich jest dozwolona itd. Nie jestem fanem tego pokolenia, ale ich lubię, ponieważ nie uważam, że jestem kimś lepszym. Jest jeszcze inne pokolenie, ci którzy lubią chodzić po nocnych berlińskich klubach i prowadzić otwarte życie. Tacy Gruzini nie są akceptowani np. w górach Chewsuretia, gdzie mają inne zasady, cerkiew gruzińska też nie jest zachwycona zachowaniem takich osób. Ja jestem przedstawicielem mojego pokolenia: nie do końca jestem liberalistą, ale też nie jestem konserwatystą. Lubię gruzińskie uczty ale znam też granice; w Wielkanoc chodzę na cmentarz, wspominając zmarłych, ale jak mam możliwości, wolę wyjechać i podróżować za granicę. Trudno także określić „prawdziwego Gruzina" - my wszyscy jesteśmy bardzo różni i równocześnie jesteśmy całością. Uważam, że prawdziwym Gruzinem jest przede wszystkim ten, kto żyje w takiej różnorodnej rzeczywistości. W Gruzji, czy poza granicami kraju, trzymając kieliszek smacznego schłodzonego Colikauri ${ }^{18}$, w języku gruzińskim wznosi toast za miłość (chrześcijańską) między ludźmi.

Ten kto myśli po gruzińsku jest Gruzinem. Jeśli cudzoziemiec nauczy się języka gruzińskiego i zacznie w tym języku myśleć, można uznać go za Gruzina. Chciałbym powiedzieć, że gdyby nie język, już dawno nie byłoby nas na świecie ${ }^{19}$.

17 Określenie Gruzina mianem „typowego Gruzina” jest po części negatywnie odbierane w Gruzji, gdyż kojarzone jest z tym, że „typowy Gruzin” posługuje się językiem rosyjskim i posiada rosyjską mentalność.

${ }_{18}$ Gruziński szczep białego winogrona.

19 We wszystkich tłumaczeniach starałam się zachować stylistykę oryginalnych wypowiedzi. 
Dzięki tendencji stworzenia swojego „mikroświata” Gruzini uratowali swoje tradycje, zwyczaje itp. przed zagranicznymi, najczęściej muzułmańskimi wrogami. Gruzinom trudno było wyobrazić sobie Gruzina bez znajomości języka gruzińskiego, ale kilka osób zaznaczyło, że pojedyncze przypadki są akceptowalne, np. jeśli ktoś się urodzi za granicą.

\section{Zarys historyczny}

Droga do zachowania języka gruzińskiego w sytuacji zagrożenia dla gruzińskiego jako języka państowego była trudna. Te procesy nie trwały przez 20-50 lat, ale o wiele dłużej. W różnych okresach historycznych Gruzja była okupowana, dzielona przez „inne”, „obce”, odległe kulturowo społeczności/narody (przede wszystkim niektóre były krajami muzułmańskimi). Kultura gruzińska mocno ucierpiała, w tym język gruziński. Ślady obecności obcych pozostały do dziś (w kulturze oraz $\mathrm{w}$ języku). W wyniku tych wpływów w języku gruzińskim jest używane słownictwo zapożyczone np. z języka tureckiego, perskiego, arabskiego, rosyjskiego ${ }^{20}$. Takie kontakty językowe w przypadku Gruzji można podzielić na trzy grupy:

- kontakty z językami, które miały wpływ na język gruziński z powodu relacji polityczno-gospodarczych Gruzji z innymi krajami (Rosja, Turcja, Persja, kraje arabskie);

- kontakty z językami narodów mniejszościowych zamieszkujących terytorium Gruzji, posługujących się innymi językami niż gruziński (Ormianie, Azerbejdżanie) ${ }^{21}$;

20 Z arabskiego: piqri (oुంł๓ం) - myśleć, amaki (sasyo) - dumny, mutaqa

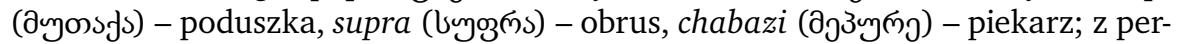

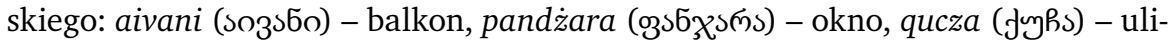

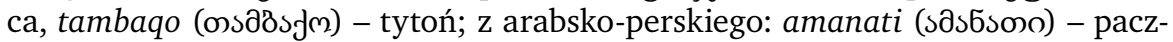
ka, zinati (\$o5sono) - bogactwo, tagliti (оsмmoоo) - oszust; z rosyjskiego: ba-

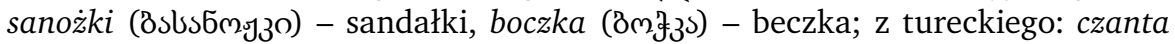
(hsбons) - torebka, otachi (mossbo) - pokój itd. Na podstawie: Słownik etymologiczny języka gruzińskiego. Internet: https://www.ice.ge/liv/liv/ganmartebiti.php (dostęp: 22.03.2021).

21 Według Głównego Urzędu Statystycznego z raportu z 2014 r. wynika, że najliczniejsze grupy etniczne zamieszkujące Gruzję to Azerbejdżanie i Ormianie. 
- kontakty z językami regionów/republik autonomicznych, które teoretycznie należą do Gruzji, ale nie posługują się językiem gruzińskim (Osetia Południowa i Abchazja).

Sytuacja językowa, czyli status języków i relacja między nimi w konkretnym administracyjno-politycznym otoczeniu, jest jednym z kluczowych pojęć w polityce językowej. Można powiedzieć, że państwo wpływa na język pośrednio (przykładowo poprzez politykę emigracyjną i imigracyjną) lub bezpośrednio (właśnie poprzez politykę językową). Sytuacja językowa jest zmienna, zależy od polityki państwowej w dwóch kontekstach, kiedy państwo samo planuje rozwój języka na swoim terytorium (relacje pomiędzy językami) oraz kiedy czynniki zewnętrzne powodują, że zmienia się sytuacja językowa w danym kraju. Takimi czynnikami zewnętrznymi w XIX i XX wieku było Imperium Rosyjskie oraz Związek Radziecki ${ }^{22}$.

Odkąd Gruzja dołączyła się do Imperium Rosyjskiego (1801-1917), w kraju można było zaobserwować pewne procesy noszące znamiona polityki językowej - negatywnej z gruzińskiego punktu widzenia. Polski kaukazoznawca Andrzej Furier dużo pisze o sytuacji językowo-tożsamościowej w Gruzji podczas panowania carskiej Rosji:

Szkolnictwo średnie było już całkowicie poddane kontroli rosyjskich inspektorów i używanie języka gruzińskiego było nawet formalnie zakazane na terenie szkół. $Z$ tego powodu dochodziło co jakiś czas do dramatycznych wydarzeń, które stawały się przyczyną społecznego oburzenia. W obronie prześladowanych za używanie języka gruzińskiego uczniów stawali przedstawiciele samorządu szlacheckiego i wybitni Gruzini, za co spotykały ich represje ${ }^{23}$.

W procesie rusyfikacji dużą rolę odegrał kapłan Rosyjskiego Kościoła Prawosławnego Joann Wostorgow ${ }^{24}$. W roku 1881 dzięki niemu wprowadzono do szkół „metodę niemowy”, która zyskała taką nazwę z po-

22 M. Tabidze, Problems of the Georgian Language and its functioning Factors in Georgia, Tbilisi 2005, s. 14.

23 A. Furier, Gruzja niepodległa. Od monarchii do republiki, Toruń 2020, s. 72.

24 Восторгов, Иван Иванович. W 2000 r. kanonizowany jako jeden z Soboru Świętych Nowomęczenników i Wyznawców Rosyjskich. 
wodu braku wspólnego języka pomiędzy nauczycielami i uczniami. Do szkół nagle sprowadzono rosyjskich nauczycieli, którzy nie mówili po gruzińsku, z kolei gruzińskie dzieci nie mówiły po rosyjsku - obie strony musiały więc komunikować się bez słów. Manana Tabidze podaje konkretne zestawienia kadry rosyjsko- i gruzińskojęzycznej w szkołach: w Gimnazjum Kutaisi na 29 nauczycieli - 4 było Gruzinami, w Gimnazjum Batumi na 19 nauczycieli - tylko 3 było Gruzinami, w Gimnazjum w Batumi dla kobiet na 20 nauczycieli - również 3 było Gruzinami, w Progimnazjum w Sochumi na 9 nauczycieli - żaden nie był Gruzinem, w innych gimnazjach także zdarzał się zupełny brak gruzińskich nauczycieli (np. uczelnia im. Mariam w Batumi itd.)25.

Po rewolucji październikowej w 1917 roku Gruzja uzyskała niepodległość. Od tego momentu powoli zaczęło się wspieranie i wzbogacanie języka gruzińskiego. Powstał pierwszy Państwowy Uniwersytet w Tbilisi oraz inne instytucje naukowe. Pierwsza Konstytucja Gruzji została przyjęta przez Zgromadzenie Konstytucyjne Gruzji 21 lutego 1921 roku. W artykule 1 rozdziału III czytamy: ,językiem państwowym Gruzji jest język gruziński"26. Był to pierwszy zapis konstytucyjny w historii gruzińskiej państwowości. Cztery dni później, 25 lutego 1921 roku, bolszewicy zaanektowali Gruzję. Od tego momentu językiem dominującym i priorytetowym stał się rosyjski, polityka językowa została tak zaprogramowana, aby współgrała z polityką radzieckąą. W Związku Radzieckim bardzo dużą rolę wyznaczono językowi rosyjskiemu: „im szybciej będziemy mówić po rosyjsku, tym szybciej zbudujemy komunizm"28.

Nowa Konstytucja Gruzińskiej SRR została przyjęta w roku 1922. Według rozdziału II, artykułu 6: „językiem państwowym gruzińskiej SRR jest język gruziński" ${ }^{29}$. W czasach Związku Radzieckiego sta-

25 M. Tabidze, Problems of the Georgian Language and its functioning Factors in Georgia, dz. cyt., s. 101.

${ }^{26}$ Konstytucja Gruzji. Internet: http://www.ice.ge/kartuliena/\# (dostęp: 25.03.2021).

27 A. Furier, Gruzja niepodległa - od monarchii do republiki, dz. cyt., s. 179-180.

28 M. Golińska, Naród radziecki w etnopolityce ZSRR, w: Tożsamości narodowe na obszarze postradzieckim. Między dziedzictwem a tradycja wynaleziona, red. P. Załęski, E. Breslavskaia, M. Włodarkiewicz, Warszawa 2012, s. 33.

29 Tamże. 
tus języka państwowego dla swoich języków - jak pisze Nino Markozia - miały tylko trzy kraje: Gruzja, Armenia i Azerbejdżan. Taki wpis w Konstytucji cały czas był utrzymywany w kolejnych latach. Dopiero w 1978 roku język gruziński stracił status języka państwowego (razem z nim ormiański i azerbejdżański) ${ }^{30}$.

W 1978 roku opublikowano projekt nowej (kolejnej) Konstytucji. W rozdziale VII, w artykule 75 czytamy: „Gruzińska Republika zezwala na używanie języka gruzińskiego $\mathrm{w}$ organach państwowych i publicznych, instytucjach kulturowych. Jej zadaniem jest również dbanie o jego rozwój" 31 . Każdy język miał te same prawa i nie było żadnych przywilejów czy też ograniczeń w kwestii ich używania. Język państwowy był definiowany jako język nadany przez Konstytucję, używany wewnątrz kraju - np. w aktach prawnych, we władzy sądowniczej, w instytucjach publicznych: „W Republice Gruzji, na zasadzie równości, we wszystkich organach i instytucjach zapewnia się korzystanie z języka rosyjskiego, a także korzystanie z innych języków, które są używane przez ludność" (artykuł 75, akapit II) ${ }^{32}$. W ustawie czytamy więc, że żaden język nie jest narzucony i nie zmusza się do korzystania z niego, istnieje równość językowa: jest dozwolony język rosyjski i inne języki, co jednak sugeruje i podkreśla ponownie wyjątkowość i dominację języka rosyjskiego ${ }^{33}$. W dniu 14 kwietnia 1978 roku w Tbilisi odbyły się manifestacje przeciwko ustawom, dzięki którym w tym samym roku pozycja języka państwowego została przywrócona ${ }^{34}$.

W Związku Radzieckim języki państwowe oprócz języka rosyjskiego miały ograniczone prawa, dlatego w latach 70. pojawił się problem dwujęzyczności, m.in. w Gruzji. Propaganda dwujęzyczności miała podstawę socjologiczno-polityczną oraz ideologiczną, według której początki funkcjonowania dwujęzyczności miały przebiegać jakby niezauważalnie, metodą małych kroków. Na pierwszym etapie wystarczyłoby znać język rosyjski na poziomie podstawowym, aby służył do

\footnotetext{
30 Tamże, s. 23-24.

${ }^{31}$ Konstytucja Gruzji, dz. cyt.

32 Tamże.

33 A. Bakradze, Pisma, Tbilisi 2002, s. 13.

34 Tamże, s. 12-14.
} 
komunikacji, a później wprowadzić go oficjalnie w republice. W rezultacie w latach 80. znajomość języka rosyjskiego była obowiązkowa dla osób, które nie były Rosjanami, ale jednocześnie Rosjanie nie musieli znać innych języków ${ }^{35}$. Na obronę dwujęzyczności, w której chodziło o konieczne wprowadzenie języka rosyjskiego, i dla wskazania korzyści z jej funkcjonowania naukowcy i politycy Związku Radzieckiego podali szereg argumentów oraz różnymi metodami starali się narzucić ją republikom:

- bilingwizm ma dobry wpływ na zdrowie oraz wydłuża życie, osoba dwujęzyczna jest bardziej rozwinięta;

- Belgia, Kanada, Szwajcaria miały stanowić przykład dobrego funkcjonowania dwujęzyczności;

- próbowano wprowadzić nową terminologię oraz nowy sposób rozumienia dotychczasowej, przykładowo: język republikopaństwowy i język ogólnopaństwowy lub język republik(owy) i język międzypaństwowy;

- materiały naukowe, książki, publikacje itp. musiały być wydawane w języku rosyjskim;

- dubbing w filmach miał być w języku rosyjskim; zachęcano w ten sposób osoby niebędące Rosjanami do nauki języka rosyjskiego, a nie innych języków, ponieważ dubbing wymuszał znajomość języka rosyjskiego;

- zachęcano do zawierania związków małżeńskich z przedstawicielami innych krajów (ale wchodzących w skład ZSRR) w celu unarodowienia populacji;

- w miejscach strategicznych - w przypadku Gruzji była to największa elektrownia wodna - przymusowo osiedlano Rosjan, aby sztucznie utworzyć rosyjskie wioski; były to działania łańcuchowe - tam otwierano rosyjskie przedszkola, szkoły itp. Jednak i tak do tych szkół w większości uczęszczały gruzińskie dzieci;

- nauka w języku rosyjskim pozwalała na kontynuowanie studiów w Rosji, co dawało realne szanse na to, że po ukończeniu studiów wyższych absolwenci będą mogli zajmować wysokie stanowiska.

35 M. Tabidze, Problems of the Georgian Language and its functioning Factors in Georgia, dz. cyt., s. 187. 
Czasami nawet nie było innej możliwości, np. w Osetii Północnej tylko do 8 klasy dzieci mogły chodzić do szkoły z językiem osetyjskim, a jeśli chciały kontynuować naukę, to mogły to robić tylko w Rosji w systemie 10-klasowym poprzedzającym studia. Z kolei w Abchazji od 5 klasy każdy przedmiot wykładany był w języku rosyjskim;

- stworzono dwujęzyczne i trójjęzyczne szkoły, np. w Gruzji w 1978 roku istniało 257 szkół dwujęzycznych i 11 trójjęzycznych. Uczniowie mogli nie uczyć się języka ojczystego czy przedmiotów mu towarzyszących, mieli prawo wyboru. Język rosyjski jako przedmiot był nauczany od 1 klasy. Liczba lekcji języka rosyjskiego była o wiele większa niż lekcji języka ojczystego. Wprowadzano też dni języka rosyjskiego, kiedy uczniowie mogli kontaktować się ze sobą tylko w języku rosyjskim. W szkołach tworzono różne szkolne teatry (przykładowo w Adżarii), które potem wystawiały spektakle właśnie w języku rosyjskim ${ }^{36}$.

Dzisiaj znajomość języka rosyjskiego kształtuje się różnie: zależy to od wieku, regionu ${ }^{37}$, interesów, potrzeb itd. The Caucasus Research Resource Centers (CRRC) jest organizacją, która zajmuje się badaniami w dziedzinie nauk społecznych i polityki publicznej na południowym Kaukazie (Gruzja, Armenia, Azerbejdżan). Organizacja prowadziła badania na temat znajomości języka rosyjskiego wśród mieszkańców państw kaukaskich. Okazało się, że wśród respondentów z Gruzji $13 \%$ nie zna języka rosyjskiego, $26 \%$ zna go na poziomie podstawowym, 38\% na poziomie średnim i $23 \%$ na poziomie zaawansowanym (2019 rok). Porównując wyniki z 2010 rokiem, można zauważyć, że nieznajomość języka rosyjskiego wzrosła zaledwie o 3\% ${ }^{38}$. W Gruzji znajomość języka rosyjskiego, jak pokazują wyniki, nadal jest na wy-

36 N. Markozia, Language discussions in the 80ies of the XX century in Georgia. (According to the press material of this period), Tbilisi 2016, s. 80-89.

37 Zachodnia część Gruzji miała większe wpływy od Rosji niż wschodnia część kraju.

38 Knowledge of Russian in Georgia. Internet: https://caucasusbarometer.org/ ge/cb2019ge/KNOWRUS/ (dostęp: 29.03.2021). 
sokim poziomie ${ }^{39}$. Ci, którzy urodzili się w ZSRR lub krótko po jego rozpadzie, musieli się uczyć języka rosyjskiego. Można powiedzieć, że 20 lat nie jest wystarczająco długim okresem, żeby całkowicie zmienić sytuację językową w kraju, który od 1801 do 1991 roku funkcjonował pod panowaniem Rosji, ale zmiany zachodzą.

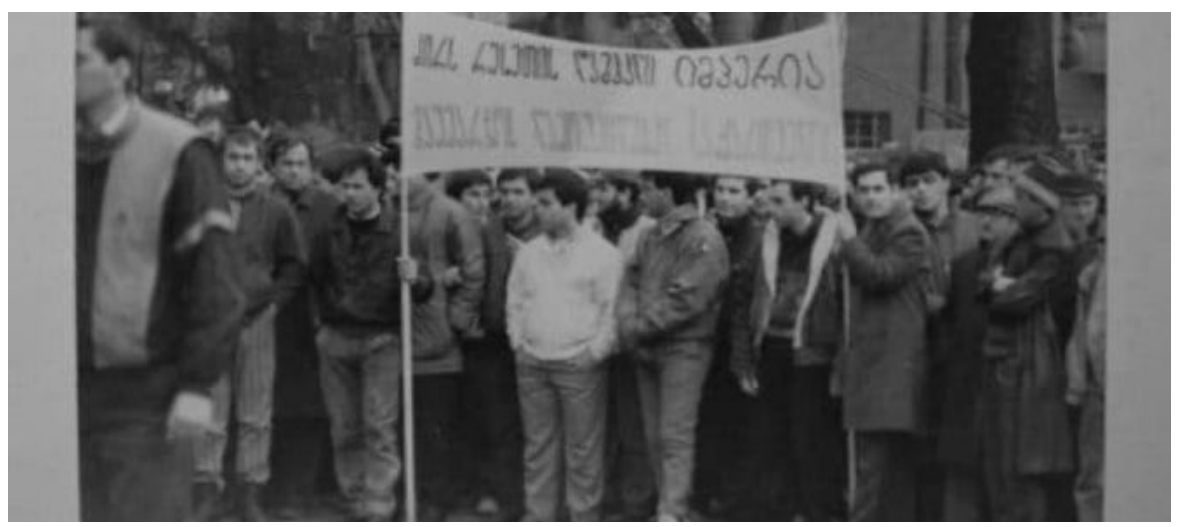

Ilustracja 1. Na banerze tekst w języku gruzińskim:

Precz ze „zgnitym” Imperium Rosyjskim! Niech żyje niepodległa Gruzja! ${ }^{40}$

Źródło: https://www.timer.ge/14-aprils-saqarthveloshi-qarthuli-enis-dacvis-dedaenis-dgheaghinishneba/ (dostęp: 25.03.2021).

\section{Państwowe reformy i języki obce w szkołach gruzińskich}

Nowe pokolenia, które są wychowywane w nowym systemie, mają inne wartości czy świadomość narodową. Zmiany w świadomości za-

39 NDI: 22\% populacji zna angielski, 66\% rosyjski. Internet: http://www.tabula.ge/ge/story/143441-ndiinglisuri-ena-mosaxleobis-22-ma-icis-rusuli-66-ma (dostęp: 29.03.2021).

40 Od 1990 r. 14 kwietnia świętuje się dzień języka ojczystego (gruzińskiego). Deda enis dge - dosłownie oznacza „dzień języka macierzystego”. Internet: https:// www.youtube.com/watch?time_continue $=16 \& \mathrm{v}=\mathrm{wXnxVspWoZU \& feature}=\mathrm{emb}$ logo (dostęp: 25.03.2021). 
uważalne były już kilka lat po upadku ZSRR. Andrzej Furier, który przeprowadził badania poświęcone tożsamości językowej Gruzinów w 1991 roku, zdecydował się powtórzyć te same badania po czterech latach. Tym razem kwestionariusze wydrukowano w języku rosyjskim. Jak komentuje autor:

było to przyczyną wielu nieżyczliwych komentarzy w trakcie badań, jak stwierdzenie „W Gruzji mówi się po gruzińsku” i trudności w wypełnianiu formularzy przez część studentów słabo znających pisownię rosyjską. Odróżniało to wyraźnie oba badania, bowiem w 1991 r. częściej używano języka rosyjskiego, wypełniając po rosyjsku nawet niektóre ankiety wydrukowane w języku gruzińskim. Po czterech latach okazało się, że respondenci zadeklarowali w większości chęć wypełniania ankiet $\mathrm{w}$ języku gruzińskim $^{41}$.

Okres postradziecki od 1991 do 2004 roku nie był szczególnie wyjątkowy pod względem polityki językowej, czego nie można powiedzieć o latach późniejszych. Wielkie zmiany nadeszły po 2005 roku, kiedy ustanowiono politykę językową na korzyść języka gruzińskiego. Po „rewolucji róż” w 2003 roku, kiedy upadł rząd Eduarda Szewardnadzego, młody przywódca Micheil Saakaszwili przeprowadził różne reformy, m.in. w systemie edukacyjnym ${ }^{42}$. Od 2005 roku zmiany stały się bardzo zauważalne w całym kraju. Saakaszwili wielokrotnie wspominał, że po reformie antykorupcyjnej i antykryminalnej modyfikacje w systemie edukacyjnym były najbardziej efektywną reformą ${ }^{43}$. Przekształcenia dotyczyły również polepszania znajomości języka państwowego, wspierania języków mniejszości oraz innowacji w zakresie nauczania języków obcych. Jeśli wcześniej (nawet po upadku Związku

41 A. Furier, Gruzja niepodległa - od monarchii do republiki, dz. cyt., s. 315.

42 Miłość Gruzji do kwiatów: rewolucja „zwiędtych róż”? Internet: http://bazhum.muzhp.pl/media//files/Wschodnioznawstwo/Wschodnioznawstwo-r2008-t2/Wschodnioznawstwor2008-t2-s45-70/Wschodnioznawstwo-r2008-t2-s45-70. pdf (dostęp: 29.03.2020).

${ }^{43}$ Najbardziej jestem dumny z reform $w$ systemie edukacyjnym. Internet: http:// www.tabula.ge/ge/story/61596mixeil-saakashvili-kvelaze-metad-ganatlebis-reformitvamakobt (dostęp: 29.03.2020). 
Radzieckiego w 1991 roku) rosyjski był wciąż dominującym językiem obcym, to po rewolucji, a szczególnie od 2010 roku, najpopularniejszym językiem obcym stał się angielski.

W kwietniu 2010 roku prezydent Gruzji ogłosił nową inicjatywę, zgodnie z którą od 1 września 2010 roku w całej Gruzji w każdej szkole miano zatrudnić nauczycieli języka angielskiego sprowadzanych z krajów, gdzie angielski był językiem państwowym/ojczystym. Według Saakaszwilego angielski mieli znać wszyscy. Prezydent sugerował telewizji, aby wszystkie filmy anglojęzyczne były emitowane z napisami, a nie z dubbingiem. Zgodnie z jego decyzjami dzieci miały się uczyć angielskiego od szkoły podstawowej, a nauczyciele, którzy znali język angielski (niezależnie od wykładanego przedmiotu) i obsługę komputera, mieli otrzymywać większą pensję.

Według projektu „Ucz i naucz się z Gruzją” w ciągu 5 lat stopniowo zamierzano sprowadzić 1000 nauczycieli do całej Gruzji ${ }^{44}$. Amerykański dziennik „The New York Times” w związku z tą akcją opublikował artykuł pod tytułem Still Fighting Russia, This Time with Words (Znowu wojna z Rosja, ale tym razem na słowa). Autor artykułu J.L. Clifford pisze, że prezydent Saakaszwili, który ukończył studia na Uniwersytecie Kolumbii w Stanach Zjednoczonych i biegle zna angielski, stara się oddalić Gruzję od wpływu Rosji i języka rosyjskiego, a także chce związać kraj ze Stanami Zjednoczonymi. Clifford wspomina czasy komunistyczne i pisze:

[...] chcieli, żeby rosyjski był drugim językiem państwowym, czasami pierwszym. Tak było od Estonii do Uzbekistanu..., ale dwie dekady temu, kiedy Związek Radziecki upadł, dużo krajów postradzieckich odrzuciło język rosyjski i na nowo odbudowało swój język ojczysty, żeby wzmacniać własną niepodległość i tożsamość narodową [...], dużo Gruzinów mających ponad 40 lat dobrze mówi po rosyjsku, ale podczas rządu Saakaszwilego zainteresowało się językiem angielskim. Rząd chce przyspieszyć ten proces $^{45}$.

44 Projekt ucz i naucz się z Gruzją. Internet: http://www.mes.gov.ge/content. php?id=1241\&lang=geo (dostęp: 29.03.2021).

45 Still Fighting Russia, This Time with Words. Internet: https://www.nytimes. com/2011/01/24/world/europe/24georgia.html (dostęp: 29.03.2021). 
W artykule zostało również przedstawione stanowisko ówczesnego ministra edukacji D. Szaszkina, który uważał, że postęp ekonomiczny można osiągnąć przez modyfikację i rozwój systemu edukacyjnego, w którym jednym z celów rządu jest to, żeby każde dziecko mówiło po angielsku: „Gruzja nie ma gazu i ropy. Zasoby, które posiadamy, to nasz ludzki potencjał intelektualny. Musimy więc wykorzystać ten potencjał w jak największym stopniu”. Dodatkowo Szaszkin wspominał, że rząd gruziński nie jest przeciwko językowi rosyjskiemu, tylko chce, żeby rosyjski był językiem obcym do wyboru podczas nauczania, tak jak niemiecki i francuski ${ }^{46}$.

Te przykłady sugerują, że od 2005 roku zaszły bardzo duże zmiany w polityce językowej, które miały również charakter kulturowy. Szaszkin podkreślił rolę anglojęzycznych nauczycieli w kulturze gruzińskiej, jego zdaniem nauczyciele mogą pomagać uczniom nie tylko językowo, ale mogą także przekazywać inne kulturowe wartości amerykańskie czy europejskie ${ }^{47}$. Dzięki wysiłkowi różnych osób, organizacji, instytucji podczas ekspansji oraz okupacji i podziału kraju (np. Imperium Rosyjskie, ZSRR) język gruziński pozostał językiem państwowym Gruzji.

\section{Nastawienie Gruzinów do języka rosyjskiego}

Gruzińsko-rosyjskie stosunki kulturowo-polityczne są cały czas napięte. Wynika to przede wszystkim z faktu, że $20 \%$ terytorium Gruzji (Abchazja, Osetia Południowa) jest zajęte przez Rosję ${ }^{48}$. To, że Gruzini są szczególnie uczuleni na język rosyjski (oczywiście nie wszyscy), wynika z życia codziennego ${ }^{49}$. Jeden z ostatnich przypadków miał miejsce w październiku 2020 roku w trakcie kampanii wyborczej do parlamentu gruzińskiego. Znana partia polityczna Zjednoczony Ruch Narodowy (liderem jest były prezydent Gruzji Micheil Saakaszwili) zorganizowa-

46 Tamże.

47 Wersja gruzińska artykułu: The New York Times. Internet: http://www.mes. gov.ge/content.php?id=1900\&lang=geo (dostęp: 29.03.2021).

48 Government of Georgia. Internet: http://gov.ge/index.php?lang_id=-\&sec_ id=288\&info_id=37863 (dostęp: 27.03.2021).

49 Można znać język obcy, a niekoniecznie lubić go lub potrzebować używać. 
ła koncert, na którym wystąpiły różne gwiazdy, m.in. Wachtang (Buba) Kikabidze $^{50}$. Kikabidze podczas swojego występu na Placu Wolności zaśpiewał piosenkę Tbiliso częściowo po rosyjsku - wywołało to ogromny rozgłos i krytykę ${ }^{51}$. Zjednoczony Ruch Narodowy jest znany ze swojej antyrosyjskiej polityki, dlatego dla wielu osób występ był ogromnym zaskoczeniem. Na stronie kanału telewizyjnego Imedy czytamy:

30 lat później, po raz pierwszy w historii niepodległej Gruzji, na Placu Wolności Buba Kikabidze [...] zaśpiewał dla Gruzji i mieszkańców Tbilisi w języku okupantów. W czasie, gdy 20 procent kraju jest okupowane, a Gruzja wciąż próbuje pozbyć się tego kraju z drutu kolczastego przy pomocy partnerów międzynarodowych, na głównym placu partia polityczna wykonała bardzo prowokacyjny krok [...] Po zaśpiewaniu Buby Kikabidze w języku rosyjskim nastąpił publiczny protest. Ruch Nacjonalistyczny został oskarżony o kolejną prowokację przeciwko krajowi ${ }^{52}$.

Artysta musiał wytłumaczyć swoje zachowanie - wyjaśnił, że zaśpiewał po rosyjsku, żeby inni zrozumieli, jaka piękna jest Gruzja. Pojawiły się także głosy, że fonogram był zmieniony, dlatego wystąpił taki błąd.

Innym przykładem pokazującym nastawienie młodych ludzi do języka rosyjskiego jest Forum Tbilisi, największy portal, na którym można dyskutować na różne tematy. Na stronie można przeczytać o inicjatywie zachęcającej do nierozmawiania w języku rosyjskim:

Na forum już wielokrotnie rozmawialiśmy, że powinniśmy unikać używania języka rosyjskiego, będzie to na ulicy, w barze, w restauracji, w hotelu czy w kawiarni... po prostu go omijać i nawet jeśli rosyjski turysta o coś zapyta, bardzo grzecznie i uprzejmie zaznacz, że nie mówimy po rosyjsku. To jest bardzo proste, naprawdę!

50 Jest znanym gruzińskim piosenkarzem i aktorem. Kikabidze zdobył popularność w czasach ZSRR, film Mimino, w którym wziął udział jako aktor, stał się popularny także w Polsce.

51 Buba Kikabidze zaśpiewał część „Tbiliso” w języku rosyjskim. Internet: https://www.youtube.com/watch?v=HpBafm5Z_C4 (dostęp: 26.03.2021).

52 Podczas występu Buba Kikabidze zaśpiewā $w$ języku rosyjskim. Internet: https://imedinews.ge/ge/politika/169827/natsionaluri-modzraobis-aqtsiaze-bubakikabidzem-rusulad-imgera (dostęp: 26.03.2021). 
[...] To jest dość prosty i zrozumiały protest przeciwko rosyjskiej polityce wobec nas, ten protest nie zagraża ani nie szkodzi żadnemu biznesowi - żadnej restauracji, żadnemu hotelowi, żadnej kawiarni, ani barowi! [...] musimy maksymalnie unikać korzystania z języka rosyjskiego, oddalać się od niego... lepiej mówić w języku angielskim, ponieważ jest językiem międzynarodowym ${ }^{53}$.

Gruziński tygodnik „Kwiris Palitra” w 2019 roku opublikował artykuł pod tytułem Czy powinniśmy zakazać stuchania rosyjskiej estrady $w$ Gruzji?. W artykule czytamy: „niedawno na Facebooku pojawiła się petycja zatytułowana: zakaz włączania rosyjskiej estrady w lokalach gastronomicznych działających na terenie Gruzji. Petycja obecnie ma ponad 1100 podpisów". Giorgi Suchiszwili, znany gruziński piosenkarz, również popiera pomysł wprowadzenia zakazu słuchania rosyjskich piosenek w miejscach publicznych, szczególnie w Gori ${ }^{54}$, i dodaje, że według niego to bardzo irytujące, ponieważ chodzi o coś więcej niż tylko o język ${ }^{55}$. Na stronie czasopisma internetowego „Interpressnews” czytamy:

Rosyjskie piosenki zakazane przez nieoficjalne zalecenia rządu nie tylko $\mathrm{w}$ restauracjach, ale także $\mathrm{w}$ radiu i telewizji. Władze zaprzeczyły tym zarzutom, jednak właściciele restauracji sami mówią, że na spotkaniu z Urzędem Skarbowym „po przyjacielsku” poproszono, aby nie puszczali rosyjskich piosenek. Minister kultury kategorycznie zaprzecza takiemu zakazowi i dodaje „to kompletny nonsens, jak można w wolnym kraju wyróżniać piosenki po języku wykonania. To stwierdzenie jest chyba bardziej mitologiczne. Nie ma takiego zakazu w prawie"s6.

53 Rosyjski język, rosyjska estrada $i$ wszystko co rosyjskie. Internet: https://forum.ge/?f=29\&showtopic=35041653 (dostęp: 25.03.2021).

5410 lat temu zaczęła się wojna w Gruzji. Walki odbywały się głównie w Cchinwali, Wąwozie Kodori oraz w Gori. Internet: https://www.rp.pl/Polityka/180809504-10-lat-temu-zaczela-sie-wojna-w-Gruzji.html (dostęp: 25.03.2021).

55 Rosyjskie piosenki $w$ Gori sq szczególnie irytujące. Internet: https://primetime. ge/rusuli-simgherebi-gorshi-gansakutrebit-gamaghizianebelia-giorgi-sukhitashvili/ (dostęp: 24.03.2021).

56 Zakaz rosyjskich piosenek. Internet: https://www.interpressnews.ge/ka/article/158841-08022011/ (dostęp: 22.03.2021). 
Pierwszy pomysł wprowadzenia zakazu słuchania piosenek w języku rosyjskim pojawił się w 2011 roku.

\section{Podsumowanie}

Jak widać, rola języka jest o tyle ważna, że nie jest on jedynie narzędziem komunikacji ani nawet tylko nośnikiem informacji kulturowych czy tradycji. Jego znajomość lub nieznajomość może budzić poczucie wyobcowania lub swojskości. Może ułatwiać komunikację, ale może też ją utrudniać. Właśnie ów podział na swojskość i obcość wpływa na kształtowanie się grup etnicznych, które mają z kolei wpływ na charakter języka i jego rozwój. Zdaniem Alicji Pstygi:

język jest więc - jako system znaków i znaczeń - jednym z wyznaczników tożsamości narodowej (grupowej), obok cech kulturowych, świadomości historycznej, jej ciągłości, tradycji, obyczajów, religii, przekazuje informacje o zjawiskach kulturowych i tożsamościowych [...], tożsamość narodowa jako swoiste locum mentalne decyduje, że pamięć i doświadczenia tożsamościowe okazują się przydatne do klasyfikowania podobieństw i różnic między ludźmi (narodami) na podstawie kryterium, jakim jest poczucie związku z jednymi i odmienności w stosunku do innych, co z kolei stało się podstawowym kryterium stanowiącym o trwałości kultur $(y)^{57}$.

Powyższe przykłady pokazują, że język może oznaczać więcej niż tylko formę komunikacji. Gruzini widzą silny związek między narodem a językiem, czego przyczyną jest m.in. długa i bogata historia języka oraz alfabetu/alfabetów gruzińskiego/gruzińskich - odrębność gruzińskiego alfabetu i języka od innych języków świata oraz charakter mieszkańców Kaukazu, w tym Gruzinów, zauważa wielu respondentów. Należy dodać, że w Gruzji nadal mieszkają wielbiciele kultury rosyjskiej i języka rosyjskiego, są również tacy, którzy neutralnie patrzą na tę „problematykę” i korzystają z języka rosyjskiego jako formy komunikacji. Mimo wszystko można powiedzieć, że Gruzini silnie identyfikują się

57 A. Pstyga, Modyfikacje jednostek frazeologicznych $w$ dyskursie medialnym jako problem translatoryczny, w: Język, tradycja, tożsamość, red. E. Rogowska-Cybulska, M. Milewska-Stawiany, Gdańsk 2013, s. 127-128. 
z językiem gruzińskim. Odrębność języka gruzińskiego, charakter Gruzinów, wartości narodu gruzińskiego, konieczność obrony języka, przeciwstawianie się uciskowi i wynarodawianiu wzmogły w Gruzinach (tak samo jak w Polakach) poczucie wagi własnego języka jako najwyższego dobra narodowego, dziedzictwa kulturowego, o które trzeba walczyć i które należy pielęgnować.

\section{Bibliografia}

Bakradze, Akaki. Pisma. Tbilisi: Wydawnictwo Intelekti, 2002.

Baranowski, Bohdan. Baranowski, Krzysztof. Historia Gruzji. Wrocław: Zakład Narodowy im. Ossolińskich, 1987.

Bugajski, Marian. Język w komunikowaniu. Warszawa: Wydawnictwo Naukowe PWN, 2006.

Castells, Manuel. Siła tożsamości, tłum. Sebastian Szymański. Warszawa: Wydawnictwo Naukowe PWN, 2008.

Furier, Andrzej. Gruzja niepodległa - od monarchii do republiki. Szczecin: Wydawnictwo Naukowe Wydziału Humanistycznego Uniwersytetu Szczecińskiego „Minerwa”, 2015.

Furier, Andrzej. Gruzja niepodległa. Od monarchii do republiki. Toruń: Wydawnictwo Adam Marszałek, 2020.

Golińska, Maria. „Naród radziecki w etnopolityce ZSRR”. W: Tożsamości narodowe na obszarze postradzieckim. Między dziedzictwem a tradycja wynaleziona, red. Piotr Załęski, Elena Breslavskaia, Marta Włodarkiewicz, 9-41. Warszawa: o Oficyna Wydawnicza Aspra-JR, 2012.

Iwańczuk, Krzysztof. Kapuśniak, Tomasz. Region Kaukazu w stosunkach międzynarodowych. Lublin: Wydawnictwo Uniwersytetu Marii Curie-Skłodowskiej, 2008.

Kaukaz: transformacja przywództwa i elit politycznych, t. 6, red. Tadeusz Bodio. Warszawa: Oficyna Wydawnicza Aspra-JR, 2012.

Lévi-Strauss, Claude. Charbonnier, Georges. Rozmowy z Claude Lévi-Straussem / Georges Charbonnier, tłum. Jacek Trznadel. Warszawa: Wydawnictwo Czytelnik, 1968. 
Markozia, Nino. Language discussions in the 80ies of the XX century in Georgia. (According to the press material of this period), ed. Manana Tabidze. Tbilisi: Wydawnictwo Tsigni, 2016.

Materski, Wojciech. Gruzja, Warszawa: Wydawnictwo Trio, 2000.

Pstyga, Alicja. „Modyfikacje jednostek frazeologicznych w dyskursie medialnym jako problem translatoryczny". W: Język, tradycja, tożsamość, red. Ewa Rogowska-Cybulska, Małgorzata Milewska-Stawiany, 127-133. Gdańsk: Wydawnictwo Uniwersytetu Gdańskiego, 2013.

Rohoziński, Jerzy. Gruzja. Poznań: Wydawnictwo Poznańskie, 2016.

Rybicki, Paweł. „Naród i państwo. Z rozważań nad relacją między dwiema postaciami wielkiej społeczności". W: Naród, kultura, osobowość: księga poświęcona Profesorowi Józefowi Chałasińskiemu, red. Antonina Kłoskowska, 487-512. Wrocław [etc.]: Zakład Narodowy im. Ossolińskich, 1983.

Tabidze, Manana. Problems of the Georgian Language and its functioning Factors in Georgia. Tbilisi: Wydawnictwo Kartuli Ena, 2005.

Tambor, Jolanta. „Brak normy dla gwary”. W: Dialektologia. Materiały pomocnicze, red. Aldona Skudrzyk, Elżbieta Rudnicka-Fira, 132-134. Katowice: Wydawnictwo Uniwersytetu Śląskiego, 2010.

Whorf, Benjamin Lee. Język, myśl i rzeczywistość, tłum. Teresa Hołówka. Warszawa: Wydawnictwo KR, 1982.

\section{Źródła internetowe}

Buba Kikabidze zaśpiewał część „Tbiliso” w języku rosyjskim. Internet: https:// www.youtube.com/watch?v=HpBafm5Z_C4 (dostęp: 26.03.2021).

Deda enis dge („dzień języka macierzystego”). Internet: https://www.youtube.com/watch?time_continue $=16 \& \mathrm{v}=\mathrm{wXnxVspWoZU} \&$ feature $=$ emb_logo (dostęp: 25.03.2021).

Dzień języka ojczystego. Internet: https://www.timer.ge/14-aprils-saqarthveloshiqarthuli-enisdacvisdedaenis-dghe-aghinishneba/ (dostęp: 25.03.2021).

[Dziesięć] 10 lat temu zaczęła się wojna w Gruzji. Walki odbywały się głównie w Cchinwali, Wawozie Kodori oraz w Gori. Internet: https://www.rp.pl/Polityka/180809504-10-lat-temu-zaczela-sie-wojna-w-Gruzji.html (dostęp: 25.03.2021).

Government of Georgia. Internet: http://gov.ge/index.php?lang_id=\&sec id=288\&info_id=37863 (dostęp: 27.03.2021).

Gruzja nie ma takiej samej pozycji jak Mołdawia, Ukraina, kraje bałtyckie pod względem rosyjskiej propagandy. Internet: https://1tv.ge/news/ian-kel- 
i-rusuli-propagandis-mkhriv-saqartvelo-ar-aris-iset-mdgomareobashi- rogorc-moldova-ukraina-baltiis-qveynebi/ (dostęp: 25.03.2021).

Knowledge of Russian in Georgia. Internet: https://caucasusbarometer.org/ge/ cb2019ge/KNOWRUS/ (dostęp: 29.03.2021).

Konstytucja Gruzji. Internet: http://www.ice.ge/kartuliena/\# (dostęp: 25.03.2021). Konstytucja Gruzji. Internet: https://matsne.gov.ge/ka/document/view/30346? publication $=35$ (dostęp: 25.03.2021).

Miłość Gruzji do kwiatów: rewolucja „zwiędłych róż”? Internet: http://bazhum. muzhp.pl/media//files/Wschodnioznawstwo/Wschodnioznawstwo-r2008-t2/Wschodnioznawstwo-r2008-t2-s45-70/Wschodnioznawstwo-r2008-t2-s45-70.pdf (dostęp: 29.03.2020).

Najbardziej jestem dumny z reform $w$ systemie edukacyjnym. Internet: http:// www.tabula.ge/ge/story/61596-mixeil-saakashvili-kvelaze-metad-ganatlebisreformit-vamakobt (dostęp: 29.03.2020).

NDI: $22 \%$ populacji zna angielski, $66 \%$ rosyjski. Internet: http://www.tabula. ge/ge/story/143441-ndi-inglisuri-ena-mosaxleobis-22-ma-icis-rusuli-66-ma (dostęp: 29.03.2021).

The New York Times [wersja gruzińska artykułu - uwaga G.P.]. Internet: http:// www.mes.gov.ge/content.php?id=1900\&lang=geo (dostęp: 29.03.2021).

Podczas występu Buba Kikabidze zaśpiewał w języku rosyjskim. Internet: https:// imedinews.ge/ge/politika/169827/natsionaluri-modzraobis-aqtsiaze-bubakikabidzem-rusulad-imgera (dostęp: 26.03.2021).

Prawie każdy Gruzin postuguje się płynnie językiem rosyjskim. Internet: https:// www.tamadatour.pl/blog/jezyk-zwyczaje-w-gruzji/ (dostęp: 22.03.2021).

Prawo o języku państwowym. Internet. https://matsne.gov.ge/ka/document/ view/2931198?publication=3 (dostęp: 4.05.2021).

Projekt ucz i naucz się z Gruzją. Internet: http://www.mes.gov.ge/content. php?id=1241\&lang=geo (dostęp: 29.03.2021).

Reforma $w$ systemie edukacyjnym. Internet: http://www.tabula.ge/ge/story/53719ganatlebisreforma-gaorebuli-sazogadoebrivi-azri (dostęp: 22.03.2021).

Rosyjski język, rosyjska estrada i wszystko co rosyjskie. Internet: https://forum. ge/?f=29\&showtopic=35041653 (dostęp: 25.03.2021).

Rosyjskie piosenki w Gori sq̨ szczególnie irytujące. Internet: https://primetime. ge/rusulisimgherebi-gorshi-gansakutrebit-gamaghizianebelia-giorgi-sukhi tashvili/ (dostęp: 24.03.2021).

Stownik etymologiczny języka gruzińskiego. Internet: https://www.ice.ge/liv/ liv/ganmartebiti.php (dostęp: 22.03.2021). 
Statystyki. Internet: https://gnta.ge/ge/\%e1\%83\%a1\%e1\%83\%a2\%e1\%83\% 90\%е1\%83\%a2\%e1\%83\%98\%e1\%83\%a1\%е1\%83\%а2\%е1\%83\%98\%e1\%83\%99\%e1\%83\%90/ (dostęp: 23.03.2021).

Still Fighting Russia, This Time with Words. Internet: https://www.nytimes. com/2011/01/24/world/europe/24georgia.html (dostęp: 29.03.2021).

Ustawa o języku państwowym. Internet: https://matsne.gov.ge/ka/document/ view/2931198?publication=3 (dostęp: 22.03.2021).

W całej Gruzji będą pracowali anglojęzyczni nauczyciele. Internet: https://www. interpressnews.ge/ka/article/130512-sakartvelos-qvela-skolashi-inglisurenovani-kveqnidan-chamosuli-inglisuri-enis-macavlebeli-imushavebs (dostęp: 29.03.2021).

Zakaz rosyjskich piosenek. Internet: https://www.interpressnews.ge/ka/article/15884108022011/ (dostęp: 22.03.2021). 